\title{
ORIGIN OF ALBITE PORPHYROBLASTS
}

SIR,-Reynolds (1942, p. 59) wrote " albite-schists . . owe their existence to introduction of sodium silicate, which ... was driven forward in advance of a syntectonic igneous mass emplaced along the axis of the Carrick Castle recumbent anticline", and cited with apparent approval in the next paragraph Read's conclusion that certain oligoclase porphyroblast schists of Aberdeenshire were formed "by transference of soda, lime, and silica from ... trondhjemite magma into the country rock", at the same time suggesting that trondhjemite is not abundant in Scotland only because it has been removed by erosion. I apologize to Dr. Reynolds if my acceptance of Dr. Jones' phrase " a trondhjemitic magmatic source" as a valid paraphrase of her views on the immediate source of the introduced sodium of the albite schists was at fault, but suggest that the best defence against misrepresentation is lucid and unambiguous exposition.

Geological Survey of Uganda,

A. F. Trendall.

P.O. Box 9,

ENTEBBE.

5th November, 1961.

\section{REFERENCE}

REYNOLDS, D. L., 1942. The albite-schists of Antrim and their petrogenetic relationship to Caledonian orogenesis. Proc. R. Irish Acad., 48, B, $43-66$.

\section{NEW RECORD OF ANTHRACONAUTA TENUIS}

SiR,--I should like to record further finds of Anthraconauta tenuis (Davies and Trueman) in North Staffordshire. The new record is from the Spoutfield Tileries of Caddick and Son, Ltd.

Early this year I received the following report from Mr. M. A. Calver, of the Geological Survey :-

"... the fauna is very similar to that which you recorded previously from Metallic Tile Co.'s pit at Bradwell and Downing's marl pit at Etruria. I am interested to see in your collection a good example of A. tenuis except that here again the specimen is somewhat smaller than the holotype, but otherwise agrees with it closely. This shell is associated with typical $A$. phillipsii and there are also intermediates between these two species. The ostracods Carbonita wardiana, $C$. pungens, and $C$. cf. humilis are also present."

Another visit to the Spoutfield Tileries was made a few months ago and more $A$. tenuis obtained. Again the specimens were found about $3 \mathrm{ft}$. 6 in. above the basal limestone of the Newcastle Beds.

148 Hempstalls Lane,

JOHN MYERS.

NeWCASTLE,

STAFFs.

19th November, 1961.

\section{REVIEW}

Crystallometry. By P. Terpstra and L. W. CodD. 420 pp., 274 figures. Longmans, London, 1961. 70 s.

This accurate, clearly written, and beautifully produced book, can be regarded as a definitive statement of the science of the measurement of interfacial angles in crystals. Full descriptions are given of different methods of deriving the crystal constants from the measured angles, and actual numerical examples abound. The numerous diagrams are all clear and elegantly drawn. 